\title{
Professional Training of Arts and Social Sciences Specialists: Cultural
}

\section{Aspect}

\author{
Zufar G. Galeev $^{1}$, Elena G. Solovyova ${ }^{1} \&$ Diana R. Sabirova ${ }^{1}$ \\ ${ }^{1}$ Kazan (Volga Region) Federal University, Kazan, Russia \\ Correspondence: Elena Solovyova, Kazan (Volga Region) Federal University, Kremlyovskaya Street 18, Kazan \\ 420008, Russia. E-mail: HelenSolovyova@mail.ru
}

\author{
Received: April 14, 2015 Accepted: April 20, 2015 Online Published: April 27, 2015 \\ doi:10.5539/jsd.v8n4p61 URL: http://dx.doi.org/10.5539/jsd.v8n4p61
}

\begin{abstract}
Importance of research of cultural aspect of professional training of the modern specialist of social and humanitarian field is conditioned by a wide range of questions, in particular, formation of a culture-friendly model of professional training of the modern specialist, reflecting the specific features of the regional cultural approach. Besides, great demands to the professional social and humanitarian education, necessity of active, independent, creative and free individual enables to create culturally, aware of human values prove the need of new approaches to the organization of educational process. It determines the importance of the research of cultural aspect of higher professional education as a whole, social and humanitarian aspect particularly. The article aims at definition of the main components of cultural aspect, reflected in a culture-friendly model of professional training of the specialist of social and humanitarian field which offers a variant of the solution of the problem of personal and professional identification of the individual in the culture, the problem which became a mainstream of humanization and humanitarisation of professional education. Main results of the article are the definition of the main components a culture-friendly model of professional training of a specialist of social and humanitarian field. Materials of the article may help in case of a better understanding of the ways of the most optimal and effective professional training in realization of educational process in the higher educational institution.
\end{abstract}

Keywords: cultural approach, civil humanistic outlook, cultural aspect of the professional training of the specialist, a culture-friendly model of professional training of the specialist

\section{Introduction}

\subsection{The Relevance of the Problem}

Global changes occurring in society, change in its value-meaningful system, implementation in the minds of youth behavioural stereotypes, values of mass culture, actualize the problem of training professionals able to accumulate and transmit values and traditions of the Russian national and regional culture. All of us being representatives of the Russian Federation and its regions are witnessing and directly experiencing the dramatic contradiction between change in the structure of the life values priorities, hence changes in culture and the opportunities we and the Russian society as a whole have. It is clear that we cannot speak about the automatic provision of these values yet.

The situation becomes even more serious due to the fact that the contradiction without getting permission, superimposed on another one, creating a whole range of issues. In this regard, there is a problem of training competent professionals who build their activities on the basis of cultural patterns and norms of life, who have ability to see and solve the current problems, who are tolerant to other cultures, able to adapt to the changing conditions of society and the labor market, who realize sociocultural meaning of their professional activities.

The problem of culture-generation model of the modern professional training of social and humanitarian field is increasingly reminding itself. Formation of this model both theoretically and practically is very significant because of its availability and implementation which in turn, contributes to solving the problem of optimal integration of a person in social and personal importance of professional activities. Cultural perspective of this problem has become the subject of our consideration.

In this regard, it is not by chance that the discussions on the reform of higher education, primarily refers to two 
problematic fields, two real-world problems (Kravets, 2010; Ashmarin, 2009; Biryukova, 2010).

The first task, the most difficult in terms of practical implementation, the researchers qualify as a social construction of the education system that meets the standards and humanistic ideals. In practice, this means that the state must guarantee their citizens the realization of humanistic rights and freedoms in education and a decent life based on that profession.

The second problem is related to the communion of the individual to the wealth of human culture in the educational process and extra-curricular forms of student activity. It aims to overcome the one-dimensionality of personality, its particularity, given by a professional specialization.

Today there is a real opportunity to give a person the right to acquire not only basic professional knowledge, but also the universal culture, moreover that in this case, and on this basis it is possible to develop all aspects of the personality. The needs of its subjective and objective conditions related to material resources and human resources education are taken into account.

At the same time, personal development in harmony with the universal culture depends on the level of development of basic humanitarian culture. It is due to this regularity cultural approach to the selection of educational content (Piralova 2014; Galaguzov, 2011; Pavlov, 2014; Afanasova 2012; Yusova, 2010). In this regard, self-identity in the global culture becomes a core line of humanization of educational content.

In this cultural approach in practical educational activities is a method of integrative holistic system of organization of educational process, determining the specific requirements for the selection of content and technology, as well as the creation of appropriate pedagogical conditions of education in accordance with the conceptual provisions ensuring the formation of the student's personality as a subject of culture on the basis of cultural continuity (Galaguzov, 2011).

Integrative this approach is reflected in the fact that it does not replace other methodological approaches that are widely used currently in educational activities, and integrates them.

It is known that the main scientific and pedagogical approaches which are intergratively combined with cultural one in educational activity are axiological, person-oriented and competence-based approaches. At all substantial and tool distinction of these methodological approaches they are united with personality of a student which is in the centre of attention of each of them, although different aspects of its purposeful development, formation in conditions and means of education are accented. It is an active personality, realizing itself in activity. Therefore personal and activity approach which now, in the conditions of humanization of the educational sphere, is in fact one of the leading methodological bases in scientific and pedagogical researches, is manifested as psychological basis of integrative methodology of cultural approach.

Sociological basis of integrative methodology cultural approach should be considered by all accounts, a socio-cultural approach has received in recent years, active development in sociology. From the perspective of this approach is understood as a society sociocultural system, arise and change as a result of actions and interactions of people, in which culture permeates all, without exception, the state of social life.

Thus, the use in the formation of cultural approach not only does not eliminate the need to use other approaches, but, on the contrary, requires their optimal combination, integration within the culture-centered educational paradigm. At the same time, the general paradigmatic preconceived determines priority in integrative methodology is cultural approach, which specifies the meaningful use of other approaches, giving them a culture-oriented.

However, the embodiment of cultural approach very complex system problem, its solution requires improving the status of the humanities, renewal, liberation from primitive edification and schematics, revealing their spirituality and human values. Account the cultural and historical traditions of the people, their unity with the universal human culture - the most important terms of designing new curricula and programs.

From the above findings of scientific novelty of the research, which is to develop a culture-variant model of modern training of specialists in social and humanitarian spheres, including the specifics of the implementation of cultural aspects of training in practical educational activities, specific requirements for the selection of content and technology, as well as determine the feasibility of teaching conditions for the formation of the individual student as the subject of culture on the basis of cultural continuity. Scientific novelty is found in the definition of some basic principles: the principle of continuous cultural continuity, the principle of personal-cultural subjectivity involved in the educational process, the principle of social and cultural integrity of the educational environment of the university and others. Also developed theoretical model parameters culture-training on the profile of social and humanitarian education. 
Culture implements its function of personality development in its training only if it activates, motivates people to work (Pokushapova, 2011). The more diverse and productive activities significant to the individual, the more effective is happening and professional mastery of universal culture.

Under these conditions, creation of cultural space - a necessary condition for the formation of a specialist with a holistic, systemic vision of the world, allowing him to successfully and flexibly adapt to the modern world. This requires such an organization of the educational process that would contribute to enculturation, socialization, intercultural communication, self-realization, the creative potential of the individual in the world of culture.

That is why the above issue led to the study of cultural urological training component of modern specialist.

\subsection{Explore Importance of the Problem}

The process of general, social, moral and professional development of the individual, that is, its professional personal training (and wider professional socialization) becomes optimal, when the student is the subject of study. And he becomes a subject only if he integrates in himself activity, sovereignty and individuality (uniqueness). This pattern causes the unity of implementation of activities and personal approaches.

It is not by chance that in the modern world of spiritual and humanitarian dimension of labor, value attitude reflects such a component (element) as professionalism. In this sense, "civil humanistic outlook", emerging in the educational space of the university in the process of training a student must be as follows:

- recognition of inherent value of human life and health, relevant to each individual as to the sovereign;

- lean attitude to nature and its wildlife, active environmental activities;

- strict compliance with universal moral norms;

- A law and law obedience;

- constant quest for mastery of acquired knowledge, strengthening efforts in the reasonable practical application;

- irrepressibility in personal self-assertion, belief in oneself and in people, inexhaustible optimism in life (Galeev \& Tikhonravov, 2014)

In our opinion it also involves the formulation of a system task of forming an "advance" consciousness of a student. Otherwise speaking it means the development of his humanitarian (implemented) thinking, the one coordinated with his scientific and technical "thesaurus". It is also necessary to strengthen his faith in his own efforts, the ability to build his relations with the outside world on the moral, spiritual value basis. Students should be taught to learn, to live along with themselves, with others and to work.

\section{Methodological Framework}

In this regard, it is clear that the course on the humanization of the educational process in general, and in particular on updating of its cultural aspect can be a major driving force of modern development of both our country and the world in general. It is not surprising, whereas the achieving by students the meaningful, value-emotive (empathy) understanding of himself and others, his personal, social and universal human motion patterns without it would be impossible. Without it, it is unreal to achieve mutual understanding between students and teachers, between people and nations.

That is the reason, but not the only one - culturologization and humanization are fundamental problems of process of the professional training of modern specialist. After all, education is the main way of human being (and therefore humanity) to himself, to well-being. Therefore, the whole system of pedagogical relationships in the college, the content of socio-humanitarian subjects, particularly cultural, it is necessary to fill with the deep worldview value specifying and informative, in other words, culturally confirmed meaning.

In this regard, let us consider the notion - "cultural conformity". It is known that even Diesterweg A. (1956), setting up the principle of cultural conformity, argued that the productive influence on the individual must comply with the spirit of the time and take into account the level of development of culture, on which the nation to which this individual belongs is. This reflects cultural conformity of upbringing. Diesterweg supposes that everyone must be a product of its time and its requirements. According to A.Diesterweg, the state of culture and the human environment make him who he is.

The principle of the cultural conformity allows education to become adequate to a modern culture, to conform to a cultural task of development community in a variety of current cultural processes.

We suppose that the cultural conformable model implies conformability to national-cultural, historical, mental, religious and other national traditions i.e. correlation of the educational process with a cultural tradition and 
culture of our time is reflected. The cultural conformable educational process takes into account the conditions of time and place in which a person was born and where he will live, takes into account the historically achieved level of culture and educational ideal society.

In the conception of the cultural conformable education is separated the notions of socialization and cultural conforming on that ground that the first one shows the process of adaptation of the individual to the "ready" social structures, and the second one captures the sources of his creative growth in a developing society. In our view, this is mutually supplementary components of a single educational process, which is formed at the same time (and self-formed), as a person and specialist. The education depends on the cultural influence: the era, the nation, the social environment, the cultural attitudes of learners themselves. The principle of the cultural conformity of education speaks of his desire to be a congruent (responded) to a culture. All the more so, because being a part of the culture, the education recreates the culture in its entirety unlike any of the other its components.

Therefore, culturally conformed educational process is a process, which includes the meaningful, institutionalized, consistent and continuous change of its components: the humanistic-oriented educational content, filling of culturally conformed context of the spatial environment of the university, cultural models of professional activity and interpersonal interaction of its main actors.

Culture programs activities at the social level as well as at the individual (Bagdasarian, 2012). In the professional activity of a specialist, this appears in the development and applying of accumulated experience. This experience helps to actualize the socio-cultural component of vocational training of a specialist, to evaluate critical situations and find a way out of them, to minimize the negative social and moral consequences of professional activity by taking the right decisions. The cultural component of vocational training of future specialists integrates social values and cultural traditions, which improve the personal culture and contribute to its fulfilment.

The value of cultural knowledge for the modern specialist consists in enculturation of personality, i.e. in its inclusion to the culture, in the awareness of its place in culture, in the choice of values (including professional). Cultural knowledge contributes to the formation of the social, ethnic, confessional and professional identities.

Besides expanding general cultural outlook, cultural subjects point at the finding and comprehension of cultural meanings of the professional activity, help to reveal professional cultural standards, contribute to the interindividual and professional intercultural development, form the professional competence.

Culturally conformed model of professional social and humanitarian sphere specialist training we offer, includes structural elements: theoretic, objective, content, technological ones (Chelyadinova, 2012).

The content of the modern professional social and humanitarian sphere specialist training forms on the integration of the following approaches basis.

Content-active approach tends to the students including in the learning, artistic and creative, value-oriented and communicative activities; it looks to the forming of crucial general cultural, professional and special competences:

- $\quad$ to be prepared to the self-determination in culture and society; capacity to the self-reflexion; ability to comprehend the cultural values; art communication need; systematic intellection;

- $\quad$ ability to transfer the cultural experience of the past to the modern life;

- $\quad$ ability to find out the mental dominant closes the works of the same or different kinds of art in a particular era;

- $\quad$ things, the phenomena of the culture, traditions, objective environment etc.;

- $\quad$ ability of creation as a way of realization of personal viewing the world in culture;

- ability to critically evaluate artistic phenomena, works of art;

- $\quad$ acquirement of the sign system of culture, consideration of the culture as a text;

- $\quad$ aggregation to the system of universal human values.

Systematic complex approach is focused on cognition of the holistic picture of the world through the culture. In the process of comprehension of social and cultural meanings of art, of considering its various forms and genres, there is the mastering of artistic-figurative language of different art forms, which contributes to plunging in different epochs and artistic styles, and most importantly - to a holistic cognition of the world picture, the comprehension of experience of creative activity. 
Personal-oriented approach is aimed to develop self-dependence, initiative sociability, reflection, creative activity; the formation of willingness of the individual to self-learning and self-development, the ability to improvise, solve problems, to have an orientation in modern information space of culture and arts; the acceptance of socio-cultural norms and the inclusion of the individual in their further development.

Regional approach is focused on accounting of traditions and culture-historical ties between Russia and Tatarstan, assume consideration of cultural peculiarities in the capital and the provinces, which contribute to the development of self-consciousness of student as a member of the ethnos group and the carrier of national culture, national identity while maintaining tolerance and the ability to intercultural dialogue.

Having denoted some general strategic ways of our problem, it is quite logical to give some examples and the types of technology from the practice of teaching cultural-logical disciplines of authors of this article, aimed at realization of content-activity, system- integrated, personality-oriented, regional approaches.

Among them: information-computer, problem-developing, play, integrative professionally orientated technology, creative, communicative technologies, teamwork, discussions, preceding independent work of students, cultural practice, etc.

All used interactive technologists, include complex components. Problem, research, creative aimed at making student in the process of comprehension of humanistic values making active subject in professional and social-cultural life.

Technological component of proposed model of specialization training in social-humanitarian sphere based on the method of projects (creative projects, problem, cultural-educational projects, and presentations) such professionally oriented projects as "Value and symbolic component of the specialist activity's content in social-humanitarian sphere", "Symbolic space and language of Islamic culture", "Business communication of East and West In modern world", "Peculiarities of Islamic culture in Volga region" etc.

Widely used methods of case studies (e.g., iconic and symbolic interpretation of urban sculpture "Kazan cat"); composition workshops that contemplate common problems of disciplines (for example, "Reflection of values in the peculiarities of cultures" et al.); teach-in ("The sacred and the secular in Contemporary Culture"); problem lectures ("Values of the specialist in professional culture in the XXI century", and others.); multimedia lectures in the centre of the "Hermitage-Kazan" ("The Return of the Prodigal Son in the painting HU1-XX cc .: the peculiarities of interpretation", "Music of the colours in the works of Matisse and Rouault Jean", "Harmony of Christian and Islamic images in art "et al.); lecture-tour with the formulation of the problem-cognitive tasks ("Illustrate the symbolism of language and symbolic and symbolic codes of Islamic art on the example of the exposure of the Centre The Hermitage-Kazan" "99 names of the Most High"), method research portfolio, developing the ability to work with different sources of information on the topic, including primary sources, educational and scientific literature (e.g. magazines "Questions of Cultural Studies", "Observatory of a Culture" and others.), fiction, online sources, Culture TV channel programs: "Artificial selection", "Bridge over the abyss", "Power of fact", "Academy", "Absolute Pitch", "Conversations about Russian culture" (E.g., "The symbolism of the eastern tradition of painting in terms of Japanese art"), etc.; game methods ("sign-symbolic codes of the Tatar art" and others.); business games, quest; analysis of the cultural practices of urban space, teamwork and many others.

Game methods in the educational activity of students have a number of functions: culture forming, cognitive, learning, communication, developmental, semiotic, educational, relaxation. The game stimulates the activity, increases interest in the studied material, and allows creating value-semantic competence. Among the games are encouraged to use role-playing, story-role, effervescence, simulation games (modelling contents and professional activity), and theatrical play retrospective reconstruction. For example, students in a real cultural-historical aesthetic environment carry out a retrospective theatrical role playing reconstruction ball where balls were held in the past century (in the Ushkovs mansion in Kazan). Ball "break out". The evolution of Russian, Western European and provincial (Kazan balls) is observed, analyses the changes the semantics of ballroom signs in time and space.

On the other hand, for example, team work on the topic "The typology of cultures" (Cultural modernization is revealed by the example of Russian culture XVIII-XIX centuries.) In preparing for class the teacher reports the topic in advance, introduces students to the goals, tasks and circumstances of the lesson. The whole group is divided into four teams: "literature", "architecture", "sculpture", "painting", corresponding to the four matters of the class. Team captains are chosen, functions are distributed within each group, etc. To enable students in independent activities in preparing for class the teacher gives preliminary homework - to prepare a presentation (for example, "Theatre of things in painting of P. Fedotov: problems of interpretation"), crossword, tests on the 
above topic. Each team is also given the task - to analyse the chosen by team kind of art of this period (based on the works of 1-2 monument of art). Options of questions, which proposed to students in advance, conform and structured in accordance with the question of the topic.

At the beginning of class, each team must demonstrate accomplishment with their homework, here: presentations, crossword, and tests on the topic. The next stage - the performance of the teams. Team's answers are organized according to the plan of proposed question options. Speaking time is subject to 10-12 minutes. In the course of performance of each team, it may sound additions from both your own and other teams (both options are evaluated). All members of teams must participate. To do this, students independently distribute answers, additional questions, etc.

For this purpose, the students independently manage the answers, additional questions, etc. At the end of the lesson, the teacher and the members of the jury generalize and assess the teams' work.

Thus, the cultural conforming model of the training of specialist of social-humanitarian sphere includes theoretical, target, informative and technological components. The main conditions ensuring the effectiveness of its operation in practice are following:

1) Cultural orientation of integrational facility of axiological, personality-activity, competence, regional, sociological approaches that focuses on enculturation and socialization of to be the social and humanitarian sphere's expert.

2) Structuring the content of the educational material with the release of significant components (knowledge, competencies, values and meanings), which are the most important in the cognitive and educational relations contributing the achievement of the unity of commonly cultural, professional and specialized competencies oriented to the quest for of socio-cultural and professional activities' cultural sense.

3) Formation of modern professional's training program content is based on the integration of informative and activity related, systematic and complex, self-oriented and regional related approaches.

4) Orientation to the development of socio-cultural experience and emotional development of the individual.

5) The selection of interactive technologies relevant to specific of educational material and the essence of culture as a polyfunctional integrative phenomenon.

6) Creativity and culturally conformed filling of content of university environment with cultural patterns of creative professional activity.

Therefore, the developed model culturally conformed formation of the modern expert, based on an integrative approach, its implementation in the educational process, and also development of a set of conditions for its effective functioning, will allow to improve the process of training the prospective specialist, to form its cultural identity, tolerance, inter-ethnic culture communication. In addition, this model will integrate the identity of the national and world culture, will help to master the national cultural traditions become culture-personality, and will contribute to the establishment of a civilian future specialist social and humanitarian sphere.

\section{Results}

The culturally conformable model of professional training in the social and humanitarian fields.

The culturally conformable model of professional training in the social and humanitarian fields represents concertedly basic structural components of university degree in the social and humanitarian fields. This model includes following components: a target component- a high priority formation of future specialists' sociocultural competence; a substantial component- the selection and amplification of the cultural aspects of the vocational education; a technological component- the use of diverse person-cantered and socially-practical professional methods for development of sociocultural and cultural competence, tolerance and subjectivity (activity, sovereignty and individuality); a component of educational environment- the filling of university educational environment with the complex of vocationally-oriented sociocultural terms and factors (Galaguzov, 2011; Yusova, 2010; Cheledinova, 2012).

In view of the foregoing, the culturally conformable model of professional training in the social and humanitarian fields includes the following components: a theoretical component, a target component, a substantial component, a technological component.

The theoretical component includes the concepts and contributions, which explain the main approaches to the problem and its solution.

The existence of the target component could be explained through the process of target setting, which determines 
the target conformable educational actions for contemporary professional training. It is the method of management, control and correction of the results of the activity with the assumed outcome. The target component is directed to the motivation for personal and professional development, self-development, self-determination in culture and understanding of cultural values. The objectives of cultural training of student's personality are directed to the creation of modern specialist. The purposes of cultural training of the identity of the student are focused on the purposes of training of the expert of a new formation.

The substantial component of estimated model opens essence of cultural aspect of vocational training of the modern expert of the social and humanitarian sphere from the point of view of his structural components and their characteristics. The substantial component includes motivational and creative, reflexive and personal components. It has to be organized so that not only to stimulate self-realization of future expert, but also to direct on judgment of professional activity, to promote development of the valuable attitude towards professional knowledge. A professionally significant knowledge, competences, values, meanings and first of all, cultural meanings of professional activity are enhanced in the content of cultural disciplines. The educational subjects filled humanistic oriented content, reflecting the national mentality, and the value of human personality in culture and spiritual values of all types of crops, traits and characteristics of national cultures, the system of social values, traditions and customs, social and cultural meanings of art, the problems associated with cross-cultural and personal communication.

Technological component contains the above-mentioned complex of modern technologies. In the integral development of its implementation they are provide the creative potential of students, the main indicator of their cultural subjectivity, and include the development of social and communicative qualities, the accumulation of subjective experience of creative activity and the social and professional interactions. Thanks to them, materialize personal-pragmatist, socio-cultural, axiological, social, professional and other set.

Technological component in their process-oriented actualization provides educational support that is consulting, modelling, design, creative solution to a set of tasks, the formation of pedagogical conditions and factors of success of the cultural aspect of training.

These components appear and realize at their respective levels: -on the level of educational goals it is the formation of socio-cultural and professional subjectivity; -on the level of education it achieved by strengthening the content of cultural aspects of training; -on the level of educational technologies provided focus on activity-assimilation of values and norms of cultural elements; -on the level of educational space formed culture-environment sphere; -on the organizational and managerial level works the formation of corporate culture of the university; -on resultant level the person reaches the status of a real subject of culture.

Development and realization of culturally conformed model of a modern specialist of socio-humanistic sphere is carried out primarily in the study of cultural disciplines of general and special (profile) cycles of master-educational process. This model is formed by taking into account the regional component. Its primary purpose is to form a professionally significant for the specialist social and humanitarian spheres of basic vocational and cultural and humanities knowledge, values, norms, attitudes and the development of emotional and motivational, volitional personality, and also the absorption of related competencies.

Therefore, the structural composition of the model suggests a variety. In addition, it integrates the most effective principles and approaches: competency-based; personality and activity; communicative, cultural.

Therefore, the model assumes a value- meaningful and informational self-determination of the prospective expert in culturally conformed educational process and in the university. This allows us to represent the process of its professional - cultural, common cultural, humanitarian and cultural, that is complete subjective self-determination as a continuous and consistent. He further includes custom components: 4 blocks, levels, stages and criteria of realization and the expected result:

- The block of aim of the structure, where the aim is defined as the promotion of a complete self-determination of the student and the structure of a holistic self-determination as a set of components:

Thus, this model assumes a value-meaningful and informational self-determination of a future expert in the culture conformable learning process and the space of the university in it. This allows us to represent the process of its professional and cultural, commonly cultural, humanitarian and cultural - that is, the holistic subjective self-determination as continuous and consistent. This further includes its own components: 4 units, levels, stages and realization criteria, and the expected result:

- the structural-objective unit, in which the goal is defined as an assistance to a holistic self-determination of the student and the structure of a holistic self-determination is defined as a set of components: 
informational-substantive, organizational-pragmatic, individual motivating; criteria are designated: cognitive, pragmatic, emotive;

- the level unit, which represents the levels of holistic socio-cultural self-determination of a student:

level 1 - the formation of a value-meaningful behaviour towards the phenomena of reality, the emergence and development of an individual's value orientations in all areas of their life;

level 2 - the level of optimal congruence (matching), where a reassessment of knowledge, values, norms, their differentiation and stabilization, construction of a hierarchy of their own scale of values and attitudes take place;

level 3 - the predictable and indicative level; here self-determination and its place in the system of values, interiorization (assimilation) of information, values and norms, self-realization, self-acceptance as a value itself are found;

- the pragmatic unit, which includes the mechanisms of holistic self-determination: reflection, choice, interiorization and exteriorization, meaning search, construction of living and professional strategies;

- the resultative unit, in which the university educational process participants' personal and professional qualities characteristics, their attitude towards life, towards future career are represented.

\section{Discussions}

The main supposition contributed to the formation of students' professional motivation is the increasing of professionalism in the world, its impact on the economy of the country and regions.

The structural components of culturally conformed model of students' training as future specialists of social and humanitarian sphere are described in the article. The analysis of the cultural aspect of the professional education of students allowed to correct and integrate, improve the practicing methods, tools and techniques promptly. The proposed model of culturally conformed, humanitarian-oriented and professionally motivating education is alternative to existing, but not taking into consideration world-wide and all Russia's experience of students training.

\section{Conclusion}

The proposed content of cultural aspect as a part of actual social-humanitarian specialist's professional preparation, as well as developed and implemented in this context cultural model of its realization meets the following principles: correspondence to the content of social-humanitarian preparation in all its elements and at all common and disciplinary aims formation levels of professional-oriented motivating training; the unity of its informative and procedural areas; content's orientation for the implementation of the qualification characteristics requirements; relevance of the cultural-related training's content to the basic types content of common and professional specialist's activity.

Furthermore, it contains the peculiarities of cultural aspect's realization in practical educational activities, particular requirements for the content and technology assortment, and the efficient, forming, teaching and sociocultural conditions of education in accordance with the conceptual statements ensuring the formation of the student's personality in the quality of a subject of culture on the basis of cultural conformity. The article also identified some basic principles: the principles of constant cultural conformity, the principle of person's cultural subjectivity involved in the educational process, the principle of social and cultural integrity of the educational environment in the university, etc. In addition, cultural model's theoretical settings are developed, which are involved in social-humanitarian section's professional preparation.

\section{Acknowledgments}

The work is performed according to the Russian Government Program of Competitive Growth of Kazan Federal University.

\section{References}

Afanasova, V. V. (2012). Kulturologichesky aspekt yazyka meditsinskikh spetsialnostey (Avtoreferat kandidatskoy dissertatsii). Moskva: 22.

Bagdasaryan, N. G. (2012). Kulturologiya: ucheb. dlya bakalavrov. Moskva: 549.

Biryukova, N. S. (2010). Gumanitarizatsiya sovremennogo obrazovaniya: filosofsky aspekt. Izvestiya Tomskogo universiteta, 6, T. 316 (ekonomika, filosofiya, sotsiologiya i kulturologiya). Tomsk: 125-128.

Chelyadinova, O. A. (2012). Formirovaniye tvorcheskoy samostoyatelnosti studentov v kulturosoobraznoy srede pedagogicheskogo vuza (Avtoreferat kandidatskoy dissertatsii). Shuya: 23. 
Disterveg A. (1956). Izbrannye pedagogicheskiye sochineniya. Moskva: 227- 235.

Galaguzov, A. N. (2011). Kulturologichesky podkhod v professionalnoy podgotovke spetsialista sotsialnoy sfery (Doktorskaya dissertatsiya). Moskva: 362.

Galeyev, Z. G., \& Tikhonravov, K. A. (2014). Dukhovno-gumanitarnye faktory ekonomicheskogo trudovogo povedeniya: monografiya. Kazan: 216.

Guskey, T. R. (2003). What makes professional development effective? Phi Delta Kappan, 84(10), 748-750. http://dx.doi.org/10.1177/003172170308401007

Kravets, A. S. (2010). Gumanizatsiya i gumanitarizatsiya vysshego obrazovaniya. Retrieved March 13, 2015, from http://www.rciade.vsu.ru/irex/puds/kravets2.htm

Pavlova, L. P. (2015, Mart 13). Kulturologichesky podkhod v obrazovatelnom protsesse. Retrieved from http://www.superinf.ru

Piralova, O. F. (2014). Sistema diagnostiki kompetentnosti inzhenernykh kadrov: avtorskaya razrabotka. Mezhdunarodny zhurnal prikladnykh i fundamentalnykh issledovany, 8(1), 153-155.

Pokushapova, P. V. (2011). Problema kachestva podgotovki sovremennogo spetsialista. Molodoy uchyony, 2, 107-109.

Seelye, H. N. (1995). Teaching culture: strategies for intercultural communication. Lincolnwood: 143.

Solovyova, E. G., \& Fakhrutdinova, G. Z. (2013). Spetsifika podgotovki bakalavrov v sisteme regionalnogo pedagogicheskogo obrazovaniya: kulturokompetentnostny podkhod. Kazanskaya nauka, 2, 190-193.

Yusova, V. I. (2010). Tsennostnoye samoopredeleniye studenta $v$ kulturosoobraznom obrazovatelnom prostranstve pedagogicheskogo kolledzha (Kandidatskaya dissertatsiya). Chita: 215.

Ashmarin, I. I. (2009). Gumanitarnaya sostavlyayushchaya universitetskogo nauchno-tekhnicheskogo obrazovaniya. Vyssheye obrazovaniye $v$ Rossii, 1, 3-14.

\section{Copyrights}

Copyright for this article is retained by the author(s), with first publication rights granted to the journal.

This is an open-access article distributed under the terms and conditions of the Creative Commons Attribution license (http://creativecommons.org/licenses/by/3.0/). 